\title{
Impact of Internal Capabilities, International Competitive Pressure and R\&D Cooperation of Firms on Their Innovation Performance: Evidence from Madagascar
}

\author{
Ida Celine Estelle Andriamihavana
}

School of Management, Shanghai University, Shanghai, China

Email address:

idatella@yahoo.fr

\section{To cite this article:}

Ida Celine Estelle Andriamihavana. Impact of Internal Capabilities, International Competitive Pressure and R\&D Cooperation of Firms on Their Innovation Performance: Evidence from Madagascar. Science Journal of Business and Management. Vol. 4, No. 2, 2016 , pp. 17-27. doi: $10.11648 /$ j.sjbm.20160402.11

Received: March 6, 2016; Accepted: March 21, 2016; Published: March 25, 2016

\begin{abstract}
On the basis of a sample of 117 firms, this study aims at investigating the effect of firms' internal capabilities consisted of Absorptive capacity, R\&D capability, Production capability and one external factor having an influence on firms such as International competitive pressure, and also R\&D Cooperation on their innovation performance with evidence from Madagascar. To test the three hypotheses formulated in this paper, a multiple linear regression is applied, with the innovation performance as the dependent variable. Our results reveal that while R\&D capability and R\&D Cooperation affect positively firms' innovation performance; Absorptive capacity, Production capability and International competitive pressure did not demonstrate any positive impact on it. Therefore, our findings highlight two major points in the context of developing countries' firms to shape and reinforce their innovation performance: to conduct R\&D activities and to engage in R\&D Cooperation as means of strengthening their internal and external capabilities.
\end{abstract}

Keywords: Internal Capabilities, Innovation Performance, R\&D Cooperation, International Competitive Pressure

\section{Introduction}

Resulting from the ongoing march of globalization and the intensity of the cross-border innovation cooperation, the study on how firms strive to reach success in Innovation performance has been broadened from the most vibrant area to the most remote one. In recent years, many studies have emerged to find out the factors conducive to firms' innovation achievement. In the context of the present study, we focus on some internal and external factors that we find significant in the analysis of innovation performance in African firms namely the level of firms' in-house capabilities such as absorptive capacity, production capability and Research and development capability, the international competitive pressure on local firms as well as Research and Development cooperation. Part of firms' effort to attain innovation performance is their focus on the enhancement of their in-house resources and operation. Lichtenthaler supported this statement by emphasizing that in an environment characterized by a lot of unpredictability, firms focus more on their internal resources in order to achieve innovation [1]. In prior literature, there is a highlight that it is within the context of rapid technological change and increased competitive pressure that firms strive to improve their internal abilities for the purpose of gaining stronger competitive advantages over their rivals. This view is shared by some authors such as [2], [3] and [4] who stressed the consequences of high competitive pressure on firms resulting on their investment on innovation activities for the purpose of improving their capabilities and also to increase their performance on innovation translated later on into their competitive advantages. As for Research \& Development Cooperation, during recent decades, some authors have increasingly turned their attention to analyzing why and how firms may choose cooperation as a strategy for innovation as well as a factor which generates the innovation performance. Some results have revealed that cooperation has been considered as an innovation stimulus and is expected to bring benefits such as achieving economies of scale and scope, reducing uncertainty, gaining access to new markets or 
accessing complementary knowledge [5, 6, 7].

Being the subject of focus in our today's dynamic and competitive environment, the importance of relying on these previously mentioned factors as ways to foster the innovation performance of firms has been well-documented in various disciplines of studies. However, their aspects have been so far analyzed in regional and national dimension or in developed and culturally-linked countries. Thus, by using a structured questionnaire survey addressed to 117 firms located in Madagascar this research challenges the existing literature by exploring the effect of these previously mentioned factors on firms' innovation performance.

Thus, this research aims at studying two major points. In the first place, it is conducted to explore the effect of some selected internal capabilities of firms such as absorptive capacity, research and development capability, production capability and one external factor consisting of international competitive pressure on firms' innovation performance. In addition, this paper studies also the effect of firms' engagement on R\&D Cooperation with other firms on their innovation performance. The structure of this paper is organized as follows. In the second section, we provide the theory and hypotheses. Then, the third section describes the methodology of the research. After that, the section four presents the results and analysis. The fifth section is devoted to the discussion. The last section is for the conclusion.

\section{Theory and Hypotheses}

\subsection{Overview of Innovation in Developing Countries}

Along with the surge of the globalization phenomenon, innovation has become in recent decades a fashionable subject and has received a growing attention all over the world. Nowadays, the interest and concern for innovation do not only involve the developed countries but also include the developing countries as they consider it to be an important element for achieving modernization [8]. But while the concept of innovation has received considerable attention and has been studied in various perspectives in developed countries, its aspect in less developed countries is still fuzzy. Only recently, there is a gradually increased awareness and particular interest devoted to the study of innovation in African countries $[8,9]$, which is considered to be the result of the intensification of the globalization process connecting countries or firms or people throughout the world regardless of their geographical distance.

Despite the fact that innovation is deemed to be a primary engine of growth and change in developed as well as developing countries $[10,11]$, the challenge this latter is facing related to this matter is still greater in terms of catching up, adoption and adaptation. Studies have revealed that the innovation climates in developing countries differed a lot from those in developed countries in many aspects. It is obviously manifest when observing the development of the innovation in advanced-economy states characterized by a smooth and well-functioning system contrary to those in developed countries still hindered by many constraints. Up to this time, the environment of innovation in Africa is hampered by many obstacles which consequently lagged them far behind the others and made them remain underdeveloped in many sectors.

\subsection{Firms' in-House Capabilities}

\subsubsection{Absorptive Capacity}

The subject of absorptive capacity is particularly vast in the literature and has been studied in various disciplines at different level. Its concept first arose from the field of Macroeconomics as the know-how of an economy to use and to absorb outside information and resources [12]. It was later on reviewed and conceptualized by Cohen and Levinthal and referred to as "the ability of an organization to recognize the value of new, external information, assimilate it, and apply it to commercial ends" [13]. This has been one of the most accepted and cited definitions of Absorptive capacity since it grasps the principal idea behind the concept and similarly appears to be straightforward and understandable [14]. Given the constant growing and relevant role of the external knowledge spillover in recent decades, absorptive capacity has captured the focus of scholars analyzing the significant phenomenon of the outside information flow. Matusik \& Heeley [15] and Camisón \& Fores [16] highlighted the role of external information for firms' internal knowledge as it is regarded to boost their innovation and competitiveness. Jiménez-Barrionuevo et al. also emphasized the necessity of the outside knowledge for firms' internal activities as it gives them the opportunity to match the acquired knowledge to their particular needs [17]. Wu and Voss pinpointed the external knowledge being absorbed and referred to it as foreign market knowledge and insisted on the importance of this knowledge for firms' international expansion [18].

Absorptive capacity of firms is recognized for its contribution to their innovation performance. Vinding using evidence from 1544 manufacturing and service industries in Denmark have found a significant linkage between firms' absorptive capacity through Human Resources Management and innovation performance [19]. Furthermore, Escribano et al.'s results of the study on external knowledge flow management have demonstrated that indeed the absorptive capacity of firms contributes to their innovation outcomes such as building their competitive advantages [20]. Cohen \& Levinthal's study on absorptive capacity also supports the idea of a link between firms' level of absorptive capacity and their innovation performance [13]. They stated that some of absorptive capacity's components are critical to firms' innovation performance. Known as firms' ability to acquire, assimilate, transform and exploit new knowledge, absorptive capacity is likewise a significant element as it enables firms to effectively use knowledge in order to improve their innovation performance $[13,21]$. Firms that recorded low in absorptive capacity doubled efforts by investing more on $\mathrm{R} \& \mathrm{D}$ or working on their workforce knowledge's skills to reinforce their internal knowledge and capabilities for the purpose of raising their absorptive capacity because the level 
of their absorptive capacity may pool their innovation performance [19]. Therefore, in the present research, we hypothesize the level of absorptive capacity of African firms as a factor that is positively related to their firms' performance of innovation.

- $\mathrm{H}_{1 \mathrm{a}}$ : Level of absorptive capacity of firms is positively related to their innovation performance.

\subsubsection{Research and Development Capability}

Many previously conducted studies have emphasized the primary role of R\&D capabilities as firms' competence in ensuring the overall factors surrounding the development of products and process to respond to the external dynamic environment. It encompasses the know-how in knowledge recombination and knowledge codification [22, 23, 24], the ability to "select, assimilate, use maintain, adapt, design and even create technology....in response to changing economic development" [25], the ability to shift and develop tacit and organizationally embedded routines involving knowledge and competence for the creation of benefits and also for the generation of innovation [26, 24]. R\&D capability also referred to as firms' "ability to restructure the current knowledge and produce new knowledge" [27, 28]. Discussed in [24] but drawn from [13, 29], one of the main roles of $\mathrm{R} \& \mathrm{D}$ capability is to "recombine existing knowledge in some novel ways to generate new, more advanced knowledge or innovations". Hence, it has been recognized as an indicator used to evaluate the success of firms $[22,28]$ as well as to enhance their competitive advantages. It has been discussed that firms trapped in a situation where their level of R\&D capabilities have revealed to be weak such as the case of African firms are more opened to the option of cooperating with other firms likely to complement them with their lack of assets. Moreover, as Zhao et al. emphasized for firms to achieve a favorable outcome in our today's turbulent environment and markets, it is primordial for them to increase effort in strengthening their in-house $R \& D$ competences [23]. Helfat [30] mentioned in [31] insisted on the importance of complementarity for enhancing firms' internal resources and capabilities. Taken from this view is the hypothesis that we test in this research which relates firms' R\&D capability level to their innovation performance. Therefore, we argue that the level of R\&D capability of firms which constitutes their internal driving factor is positively related to their innovation performance.

- $\mathrm{H}_{1 \mathrm{~b}}$ : Level of $\mathrm{R} \& \mathrm{D}$ capability of firms is positively related to their innovation performance.

\subsubsection{Production Capability}

Due to the global dynamic and competitive environment surrounding the firms' activities, we have recently witnessed an increase of awareness and concerns through the literature regarding the firms' capabilities [32, 33, 26, 34], with the aim of grasping the nature and the dynamism of the production to be drawn up [33]. Thus, we have retained two definitions that highlight the relevance of the production capability as being an essential ingredient of firms' capabilities. The first definition that we put forth is taken from Rejal: "production capability is firms' ability to integrate, build and reconfigure internal and external production competencies to address rapidly changing environments" [33]. It implies firms' knowhow in dealing with their entire activities related to production whether inside or outside their firm in a dynamic environment. The second definition offered by Asley $\mathrm{T}$. Celikel consists of setting the production capability as "firms' ability and competency in production and quality in control and testing" [26]. In her work, Rejal has emphasized the contribution of the production capability in maintaining a competitive advantage to firms and in contributing to their performance [33]. She underlined as well that the concern related to production capability encompasses both firms in developed and developing countries as it is considered to be one of the tools to comprehend the relevancy of their production [33]. Nevertheless, the issue for firms in developing countries turns out to be greater. Production capability is perceived of great significance for these firms as most of them are involved in the activity of production and export abroad. However, along the surge of the globalization and the intensity of competition in the global market which stress the need to innovate, these firms face many challenges in terms of low internal capabilities and non-availability of strategy to promote innovation. Firms in developing countries encounter this problem due to some complexity related to their business landscape and also to their low pace of innovation. From this perspective, we argue the level of firms' production capability to contribute to their innovation performance. Trapped in a situation in which their option is to strengthen their internal sources or to be out of the competition race these firms strive to enhance their limited resources for the purpose of upgrading their innovation performance.

- $\mathrm{H}_{1 \mathrm{c}}$ : Level of production capability of firms is positively related to their innovation performance.

\subsubsection{International Competitive Pressure}

There is a common agreement in the research field on the intensity of competition in the global market environment, which resulted in low competence firms to be under constant pressure. Compared to those in developed countries, firms in developing countries are still lagging far behind in terms of level of capabilities and capacity, which put them in a vulnerable position when faced with strong competition. There is a widespread belief that the intensity of competitive pressure on firms is one of the incentives which triggers their decision to get involved in innovation activities. As asserted by Schumpeter in his study, firms are more likely to engage in innovation activities and also decide on how much to invest because of the intensity of the competitive pressure they are going through [29]. This argument is supported by Crepon et al. in their research as they stated that the intensity of competition arouses firms' motivation to undertake the innovation [35]. This statement is also in line with Nickell who supports the idea that competition favors innovations [36]. In their study of Internal and External R\&D, A. Piga and M. Vivarelli have as well found a positive relationship 
between the competitive pressure and firms' innovative behavior [37]. For them, firms encountering high competitive pressure tend to be more involved in innovative activities. Thus, due to the global dynamic competitive environment, firms are compelled to undertake innovation activities such as increasing their R\&D activities, improving their internal capabilities and their investment. Consistent with the empirical predictions of [38] and also in agreement with [3], Benito et al. have demonstrated that the competitive pressure acts as incentives for firms to embark on innovation activities in order to deal with the competition in the market [39]. In addition, as S. Duchek argued, when there is strong competitive pressure firms are being compelled to open up their innovation process and opt for the use of external knowledge sources to increase their innovative potential [40]. The hypothesis tested in this paper is linked to firms' international competitive pressure which states that this latter is positively related to innovation performance of local African firms. The relationship between the competitive pressure and firms' innovation performance is well documented in the literature. There is even a common agreement that the competitive pressure generated by the high intensity of competition in the global market enhances firms' innovation performance. For instance, in their study investigating the role of external factors on firms' productivity growth, Nickell et al. raised an important argument pointing managers' efforts in reducing costs and increasing incentives when faced with intense competitive pressure [41]. Using evidence from 580 UK manufacturing companies they have further demonstrated in their results a positive effect of these external factors (competition, pressure and shareholders) on firms' innovation performance through the growth of their productivity. The paper of Vives analyzing the effect of competition on firms' product and process innovation also supports this argument as their analysis yielded a positive result of competitive pressure on firms' innovation activities which in turn affect their innovation performance [38]. Conducting research on the impact of competitive pressure on firms to innovate, Boone found that the effect of increased competitive pressure on firms' product or process innovation is in function of their level of efficiency which would determine its positive or negative effect [3]. Some authors emphasize the effect of intense pressure generated by competition on firms' decision to upgrade their resources in order to enhance their performance of innovation and to gain competitive advantages $[2,4]$.

- $\mathrm{H}_{2}$ : International competitive pressure is positively related to local firms' innovation performance.

\subsubsection{Research and Development Cooperation}

There is an abundant resources-based view highlighting the importance and role of R\&D cooperation for firms. Most of the R\&D cooperation are conducted by firms with the aim of taking advantages of this cooperation to acquire or complement the missing resources in the case of low performing firms, and to share risks or cost as well as uncertainties related to technological operation for firms with a rather stable activity. The incentives of firms to embark on $\mathrm{R} \& \mathrm{D}$ cooperation are widely discussed in the prior literature. Many authors agreed upon the fact that $R \& D$ cooperation occurs as a result of some constraints or triggers experienced by the firms in their internal as well as their external environment. Veugelers and Cassiman [42] related to these capability constraints as constraints of Research and Development while Mowery et al. [43] associated it with technological capability constraints. The dearth resources of firms related to their in-house capabilities determine their use of alliances for the purpose of acquiring capabilities from partners. Many scholars have supported this statement by suggesting that the rationale of the cooperation is based on the gaining access to other cooperating partners' capabilities which aims at enhancing the existing capabilities of the firms [43]. The rationale for firms' involvement in $R \& D$ cooperation is not only for addressing the problem connected to their in-house capabilities but also targeting the success in their performance of innovation. In other words, firms likewise engage in innovation cooperation mode for the purpose of enhancing their level of innovation performance that will be translated thereafter into their unique and competitive advantages over their rivals. Thus, we hypothesize $R \& D$ cooperation as having a positive influence on African local firms' innovation performance.

- $\mathrm{H}_{3}$ : Firms' engagement in $\mathrm{R} \& \mathrm{D}$ cooperation is positively related to their innovation performance

\subsubsection{Innovation Performance}

Innovation performance reflects the result of a longestablished effort of firms and symbolizes the outcomes or achievements of activities performed within and outside their organization. In general, the success of the innovation performance of firms can only be determined through the innovation outputs or changes occurring after involving in any $R \& D$ cooperation as well as activities related to the enhancement of firms' in-house capabilities. To illustrate, using data on large sample of Dutch firms involved in innovation, Belderbos et al. have analyzed the innovation performance of firms in terms of labor productivity and innovative sales productivity, and supported the positive role of R\&D cooperation on it [44]. Aschhoff and Schmidt contributed as well to the rich literature of innovation performance by conducting a study on the effect of R\&D cooperation on this latter through firms' sale of innovative products and reduction of costs related to innovation process [45]. When focusing on firms' achievement on innovation, it is important to highlight that the business environment in which firms operate nowadays has changed considerably and depicts an unstable landscape in terms of riskiness, high level of competition...etc.[46]. Thus, firms to be able to catch up have to work constantly on how to perform better. This effort can be accomplished by involving in external cooperation with potential partners or by exploiting their internal capabilities for better improvement. Besides that, Crepon et al. directed firms' effort to embark on R\&D activities in order 
to be more innovative and competent [35]. They further added that the intensity of competitive pressure compels firms to involve on these previously mentioned activities, which consequently impact the success of their innovation performance.

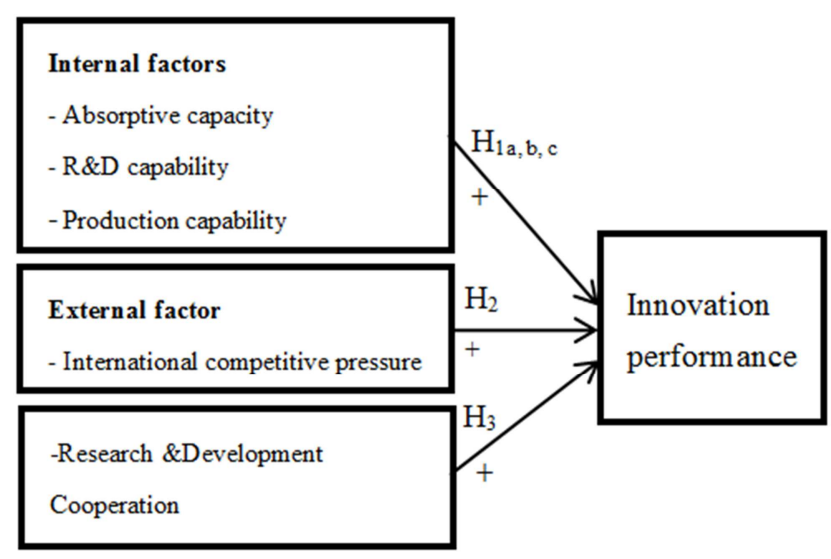

Fig. 1. Conceptual model.

In our present research, we proposed three hypotheses, and it is shown in Fig. 1. We selected firms' in-house capabilities such as Absorptive capacity, R\&D capability, Production capacity and one external factor as International competitive pressure, and discussed their effect on firms' Innovation performance. Besides, we explored the effect of R\&D Cooperation of firms on their innovation performance. Therefore, we identified five antecedents in our research framework namely absorptive capacity, R\&D capability, Production capacity as internal factors, and one external factor the International competitive pressure and $R \& D$ Cooperation as well and one consequent which is firms' Innovation performance.

\section{Research Methodology}

\subsection{Data Source, Data Collection and Survey Design}

The population set in our study consists of the manufacturing firms located in Madagascar. Given the frequent novelty and intense competition faced by these firms in the global markets, they are likely to integrate innovation in their effort to remain in line with their foreign counterparts and to gain some competitive advantages over their rivals. Thus, they are regarded as important element fitting the content of our study and were included in our sample. The manufacturing industries in Madagascar are distributed in different sectors such as Agrifood sector, Automotive sector, Energy and Mining sector, Fisheries sector and Textile industries. Hence, our sample was selected from these sectors where most of the SME and large enterprises are concentrated.

Prior step in conducting the survey was to develop a list of reliable firms fitting the content of our study. For doing so, we sought assistance from National Institute of Statistics in Madagascar (INSTAT) to obtain the basic information (Lists, names, contacts, addresses and sector of activity) about these companies. Once the lists obtained, the questionnaires were sent by email to the 150 firms eligible for our survey. In our study, we designed the survey questionnaire in a form of fillable PDF version so that the respondents filled it out in their own convenience and benefited time-saving as well. To ensure that these companies will take part in the survey, we followed up our mail survey by giving the respondents a call to inform them about the mail sent. In order to prevent a low response rate, a frequent reminding email was sent to the respondents until our set deadline of data gathering, which lasted for 5 months. To guarantee the reliability and validity of the responses, the respondents were chosen carefully. They are those who are knowledgeable in the companies and are more familiar with the issues being surveyed and also those more willing to communicate about them.

As the unit of analysis in our study consists of firms, we designed our questionnaire based on previous studies conducted by some researchers on Absorptive capacity [18, 47], on R\&D capability [23, 28], on Production capability $[26,33]$; on competitive pressure $[4,48]$, on $R \& D$ cooperation $[49,42,44,50]$ and on Innovation performance $[51,14,52]$. Thus, the designed questionnaires covered a variety of area that is relevant for manufacturing industries sectors.

\subsection{Measurement}

In our investigation, respondents were asked to answer some questions linked to our different constructs. A summary of the constructs, their corresponding measurement items as well as their sources are presented in Table 1. The independents and dependents variables' measurements observed in this study were selected according to the theoretical and empirical results from the literature reviews. Besides, we complemented them with additional questions that we designed for supplemented information needed in our context. Thus, the questionnaire form consisted of seven different parts. The first part of our study involved information about us, the objective of the survey and some questions meant to acquire the basic information about the company. Supplementary information guarantying respondents the confidentiality of the data obtained and the anonymous character of the survey were provided. The remained six sections of the survey questionnaire involved respectively questions related to Absorptive capacity, R\&D capability, Production capability, International competitive pressure, and R\&D Cooperation and Innovation performance.

\subsection{Method}

The statistical analysis in this research paper was performed using SPSS, a widely used program to produce a variety of data analysis from questionnaire surveys or other sources. The analyses in our study are based on ordinary multiple linear regression. The multiple linear regression has in general the following form:

$$
\mathrm{Y}=a+\beta_{1} * \mathrm{X}_{1}+\beta_{2} * \mathrm{X}_{2}+\ldots+\beta_{\mathrm{p}} * \mathrm{X}_{\mathrm{p}}, \mathrm{p}=1 \ldots \mathrm{n} .
$$


Where $a$ is the intercept parameter and $\beta$ is the coefficient of parameter. Therefore, the equation of our model was specified as follows:

Innovation performance $=a+\beta_{1} *$ Absorptive capacity +

\author{
$\beta_{2} *$ Research \&Development capability + \\ $\beta_{3} *$ Production capability + \\ $\beta_{4} *$ International competitive pressure + \\ $\beta_{5} *$ Research \&Development Cooperation
}

Table 1. Description and measurements of variables.

\begin{tabular}{|c|c|c|c|c|}
\hline Variables & Items & Sources & No. Indicators & Measurements \\
\hline \multirow{2}{*}{$\begin{array}{l}\text { - Absorptive } \\
\text { capacity }\end{array}$} & - Firms' ability to integrate and apply knowledge & $-[18]$ & $(5)$ & - Likert- scale 1-5 \\
\hline & $\begin{array}{l}\text { - Firms' involvement in cooperation with external agents for knowledge } \\
\text { acquisition }\end{array}$ & $-[47]$ & (1) & - Likert- scale 1-5 \\
\hline \multirow{2}{*}{$\begin{array}{l}\text { - R\&D } \\
\text { capability }\end{array}$} & - Firms' perception of the level of their R\&D capability and its current status & $-[23,28]$ & (5) & - Likert- scale $1-5$ \\
\hline & - R\&D intensity & $-[53]$ & (1) & - Likert- scale 1-5 \\
\hline \multirow{3}{*}{$\begin{array}{l}\text { - Production } \\
\text { capability }\end{array}$} & - Firms' perception about their level of competence in production & $-[26]$ & (6) & - Likert- scale 1-5 \\
\hline & - Significance of the production capability of firms & $-[33]$ & (3) & - Likert- scale 1-5 \\
\hline & - Export capacity & $-[54,55]$ & (1) & - Likert- scale 1-5 \\
\hline \multirow{2}{*}{$\begin{array}{l}\text {-International } \\
\text { competitive } \\
\text { pressure }\end{array}$} & - Firms' perceptions about their competitive environment & $-[4]$ & (1) & - Likert- scale 1-5 \\
\hline & - Firms' behavior due to intense competitive pressure & $-[48,56]$ & (4) & - Likert- scale 1-5 \\
\hline \multirow{2}{*}{$\begin{array}{l}\text { - R\&D } \\
\text { cooperation }\end{array}$} & - Engagement in joint R\&D with other firms and institutions & $-[49,42]$ & (1) & - Binary variable \\
\hline & - Types of partners with whom firms engaged in R\&D cooperation & $-[44,50,52]$ & (6) & - Binary variable \\
\hline \multirow{2}{*}{$\begin{array}{l}\text { - Innovation } \\
\text { performance }\end{array}$} & - Assessed result of $R \& D$ cooperation for firms & $-[51,[14]$ & (6) & - Likert- scale 1-5 \\
\hline & - Annual turnover rate of new products & $-[52]$ & (1) & - Likert- scale 1-5 \\
\hline
\end{tabular}

\subsection{Sample}

The sample in our study comprises 117 valid cases of manufacturing firms from Madagascar after the overall gathering of data and 10 rejected due incomplete responses. The effective response rate was $78 \%$. The characteristics of the sample are shown in Table 2 in which the basic overview of the surveyed firms in terms of age, employees' numbers and their annual turnover is displayed. The firm size was evaluated according to their employees' numbers. In our study, the firm is considered small (S) when its employees are less than 50 employees. It is classified as medium (M) if it has between 50 and 500 employees. It is large (L) when it has between 501 and 1000 employees and very large (VL) with more than 1000 employees. In our research, $\mathrm{S}=7.7 \%$, $\mathrm{M}=48.7 \%, \mathrm{~L}=34.2 \%$ and $\mathrm{VL}=9.4 \%$. These firms' age and annual turnover are also shown in Table 2.

Table 2. Characteristics of the sample.

\begin{tabular}{lll}
\hline Characteristics & Number of Enterprises & Percentage \\
\hline Age & & \\
$<5$ & 7 & 6 \\
$6-10$ & 25 & 21.4 \\
$11-15$ & 20 & 17.1 \\
$16-20$ & 38 & 32.5 \\
$>20$ & 27 & 23.1 \\
Number of employees & & \\
$<50$ & 9 & 7.7 \\
$50-500$ & 57 & 48.7 \\
$501-1000$ & 40 & 34.2 \\
$>1000$ & 11 & 9.4 \\
\hline
\end{tabular}

\begin{tabular}{lll}
\hline Characteristics & Number of Enterprises & Percentage \\
\hline $\begin{array}{l}\text { Annual turnover (Billion Ariary) } \\
<1\end{array}$ & & \\
$1-2$ & 6 & 5.1 \\
$2-10$ & 22 & 18.8 \\
$10-20$ & 62 & 53 \\
$>20$ & 12 & 10.3 \\
Total & 15 & 12.8 \\
\hline & 117 & 100 \\
\hline
\end{tabular}

\section{Results and Analysis}

\subsection{Descriptive Statistics}

In this section, the summary of the descriptive statistics of the different constructs is presented in Tab. 3 in which the mean, standard deviation as well as the Cronbach $\alpha$ coefficient of each construct are shown. All variables in our study appeared to have a good internal consistency and proved to be worthy of retention as their Cronbach $\alpha$ coefficient are all greater than 0.7 , which is within the acceptable range. It is indicated in Nunnally, a Cronbach $\alpha$ equals to 0.7 or greater confirms acceptable levels of reliability [57].

An analysis of the correlation was also performed in this study to measure the degree of correlation between our constructs. It is presented in Tab. 4. It is indicated that most of our constructs' correlation are greater than zero with $p$ reveals to be significant for most of them $(p<0.01)$, a high statistical significance. As the acceptable range is $[-1 ;+1]$, most of our correlations' values are closer to 1 , which signifies the positive association between the constructs. 


\subsection{Regression Analysis}

In our research, to detect the possible link and impact of our predictor variables on our dependent variable, we performed regression analysis which is presented in tab. 5 . For the first model in the regression results, we observed four variables where Innovation performance is the dependent variable and Absorptive capacity, Research and Development capability, and Production capacity are the independent variables. The adjusted R2 of our three independents variables is 0.760 indicating that these latter explains $76 \%$ of the variance of the Innovation performance of firms in our sample. The F-statistic, known as the test of significance of the multiple linear regression is also presented in the tab. 5. Its value in our model 1 is 123.757 (with $p<0.01$ ) which is highly significant indicating that there is a linear relationship between variables in our model. While R\&D capability shows a positive impact on innovation performance, both Absorptive capacity and production capability do not demonstrate any effect on it. Our second model 2 introduced the independent variable International competitive pressure. We found the adjusted R2 in our model 2 is 0.765 . This means that the linear regression with the independent variable International competitive pressure included explains $76.5 \%$ of the variance of the Innovation performance of firms. Our model showed the F-statistics value of 95.586, which is also proved to be significant as well as in the model 1 with $p<0.01$. We found in the result in model 2 that the international competitive pressure does not generate any positive effect on firms' innovation performance as its coefficient $(-0.137)$ reveals to be negative and not significant at all. The model 3 in our regression analysis releases all predictor variables on Innovation performance. The result displayed a value of 0.793 of the adjusted R2 indicating that these variables explain $79.3 \%$ of the variance of the firms' Innovation performance. The values of F-statistics is 89.91 showing a high significance level with $\mathrm{p}<0.01$. The result indicates that in our hypothesis 1 , only the independent variable R\&D capability $(\mathrm{H} 1 \mathrm{~b})$ has a positive significant coefficient $(0.793)$ with $t$-value $7.783(t-s>2)$, indicating a high impact on firms' innovation performance. In general, a t-value of 2 or higher indicates statistical significance. Thus, our hypothesis $1 \mathrm{~b}$ is supported. This significance can be interpreted as a positive impact of Research and Development capability on the Innovation performance of firms, more precisely when firms' Research and Development capability improves of one additional unit, the Innovation performance then increases of 0.793. Still in hypothesis 1, our hypothesis $1 \mathrm{a}$ and $1 \mathrm{c}$ have negative coefficients rejecting the hypotheses $\mathrm{H} 1 \mathrm{a}$ and $\mathrm{H} 1 \mathrm{c}$.Our hypothesis $\mathrm{H} 2$ is not supported as well because the dependent variable International competitive pressure has a negative coefficient. As for the hypothesis $3(\mathrm{H} 3)$, it is much supported because it shows a significant positive coefficient (1.154). It means that the engagement of firms in R\&D Cooperation impacts positively their innovation performance.
Table 3. Descriptive Statistics: Means, Standard deviation (SD) and internal consistencies of scale constructs.

\begin{tabular}{|c|c|c|c|c|}
\hline Constructs & Items & Means & S.D & Cronbach $\alpha$ \\
\hline \multirow{6}{*}{$\begin{array}{l}\text { Absorptive Capacity } \\
\text { (AC) }\end{array}$} & $\mathrm{AC} 1$ & 2.12 & 0.842 & \multirow{6}{*}{0.965} \\
\hline & $\mathrm{AC} 2$ & 2.10 & 0.855 & \\
\hline & $\mathrm{AC} 3$ & 1.88 & 0.842 & \\
\hline & $\mathrm{AC} 4$ & 1.95 & 0.945 & \\
\hline & AC5 & 2.06 & 0.884 & \\
\hline & AC6 & 1.99 & 1.126 & \\
\hline \multirow{6}{*}{$\begin{array}{l}\text { R\&D Capability } \\
\text { (RDC) }\end{array}$} & $\mathrm{RDC1}$ & 1.79 & 1.055 & \multirow{6}{*}{0.967} \\
\hline & RDC2 & 1.75 & 0.991 & \\
\hline & $\mathrm{RDC} 3$ & 1.95 & 1.202 & \\
\hline & RDC4 & 1.75 & 0.918 & \\
\hline & RDC5 & 2.28 & 1.536 & \\
\hline & RDC6 & 1.78 & 1.035 & \\
\hline \multirow{10}{*}{$\begin{array}{l}\text { Production Capability } \\
\text { (PC) }\end{array}$} & PC1 & 4.98 & 0.130 & \multirow{10}{*}{0.77} \\
\hline & PC2 & 4.14 & 0.472 & \\
\hline & $\mathrm{PC} 3$ & 2.94 & 0.994 & \\
\hline & PC4 & 3.06 & 0.950 & \\
\hline & PC5 & 3.14 & 0.600 & \\
\hline & PC6 & 3.15 & 1.031 & \\
\hline & PC7 & 2.85 & 1.022 & \\
\hline & PC8 & 2.83 & 1.116 & \\
\hline & PC9 & 2.62 & 0.869 & \\
\hline & PC10 & 4.00 & 1.075 & \\
\hline \multirow{5}{*}{$\begin{array}{l}\text { International } \\
\text { Competitive Pressure } \\
\text { (ICP) }\end{array}$} & ICP1 & 2.97 & 0.942 & \multirow{5}{*}{0.865} \\
\hline & ICP2 & 3.56 & 0.724 & \\
\hline & ICP3 & 3.64 & 0.688 & \\
\hline & ICP4 & 2.71 & 0.788 & \\
\hline & ICP5 & 2.85 & 0.843 & \\
\hline \multirow{7}{*}{$\begin{array}{l}\text { R\&D Cooperation } \\
\text { (RDCOP) }\end{array}$} & RDCOP1 & 0.56 & 0.499 & \multirow{7}{*}{0.9} \\
\hline & RDCOP2 & 0.38 & 0.489 & \\
\hline & RDCOP3 & 0.56 & 0.499 & \\
\hline & RDCOP4 & 0.09 & 0.281 & \\
\hline & RDCOP5 & 0.19 & 0.392 & \\
\hline & RDCOP6 & 0.24 & 0.429 & \\
\hline & RDCOP7 & 0.33 & 0.473 & \\
\hline \multirow{7}{*}{$\begin{array}{l}\text { Innovation } \\
\text { Performance (IP) }\end{array}$} & IP1 & 2.12 & 1.240 & \multirow{7}{*}{0.954} \\
\hline & IP2 & 2.13 & 1.256 & \\
\hline & IP3 & 2.46 & 1.236 & \\
\hline & IP4 & 2.13 & 1.236 & \\
\hline & IP5 & 2.12 & 1.247 & \\
\hline & IP6 & 2.06 & 1.198 & \\
\hline & IP7 & 1.64 & 0.725 & \\
\hline
\end{tabular}

Table 4. Inter-variable Correlation. ${ }^{*} p<0.05 .{ }^{* *} p<0.01$.

\begin{tabular}{|c|c|c|c|c|c|c|}
\hline \multicolumn{7}{|c|}{ Pearson Correlations } \\
\hline & AC & RDC & PC & ICP & RDCOP & IP \\
\hline $\mathrm{AC}$ & 1 & & & & & \\
\hline RDC & $0.836^{* *}$ & 1 & & & & \\
\hline $\mathrm{PC}$ & $0.749 * *$ & $0.795 * *$ & 1 & & & \\
\hline ICP & 0.159 & $0.233 *$ & 0.175 & 1 & & \\
\hline RDCOP & $0.775^{* *}$ & $0.876^{* *}$ & $0.817 * *$ & $0.256^{* *}$ & 1 & \\
\hline IP & $0.690^{* *}$ & $0.873 * *$ & $0.674 * *$ & 0.128 & $0.825 * *$ & 1 \\
\hline
\end{tabular}


Table 5. Regression analysis on Innovation performance as dependent variable. $N=117$.

\begin{tabular}{|c|c|c|c|c|c|c|c|c|}
\hline \multicolumn{2}{|c|}{ Model } & \multirow{2}{*}{$\begin{array}{l}\text { B } \\
0.726\end{array}$} & \multirow{2}{*}{$\begin{array}{l}\begin{array}{l}\text { Std. } \\
\text { Error }\end{array} \\
0.425\end{array}$} & \multirow{2}{*}{$\begin{array}{l}\text { t-statistics } \\
1.709\end{array}$} & \multirow{2}{*}{$\begin{array}{l}\text { R2 } \\
0.767\end{array}$} & \multirow{2}{*}{$\begin{array}{l}\text { Adj. R2 } \\
0.760\end{array}$} & \multirow{2}{*}{$\begin{array}{l}\text { F-statistics } \\
123.757\end{array}$} & \multirow{2}{*}{$\begin{array}{l}\begin{array}{l}\text { Degree of } \\
\text { freedom }\end{array} \\
3\end{array}$} \\
\hline & (Constant) & & & & & & & \\
\hline 1 & Absorptive Capacity & -0.151 & 0.105 & -1.438 & \multirow{8}{*}{0.773} & \multirow{8}{*}{0.765} & \multirow{8}{*}{95.586} & \multirow{8}{*}{4} \\
\hline 1 & Research \& Development Capability & $0.979^{* *}$ & 0.092 & 10.648 & & & & \\
\hline & Production Capability & -0.051 & 0.160 & -0.320 & & & & \\
\hline \multirow{5}{*}{2} & (Constant) & $1.129^{*}$ & 0.475 & 2.379 & & & & \\
\hline & Absorptive Capacity & -0.163 & 0.104 & -1.569 & & & & \\
\hline & Research \& Development Capability & $1.007^{* *}$ & 0.092 & 10.912 & & & & \\
\hline & Production Capability & -0.051 & 0.159 & -0.324 & & & & \\
\hline & International Competitive Pressure & -0.137 & 0.075 & -1.830 & & & & \\
\hline \multirow{6}{*}{3} & (Constant) & $2.179^{* *}$ & 0.517 & 4.213 & \multirow[t]{6}{*}{0.803} & \multirow[t]{6}{*}{0.793} & \multirow[t]{6}{*}{89.91} & \multirow[t]{6}{*}{5} \\
\hline & Absorptive Capacity $\left(\mathrm{H}_{1 \mathrm{a}}\right)$ & -0.193 & 0.098 & -1.966 & & & & \\
\hline & Research \& Development Capability $\left(\mathrm{H}_{1 \mathrm{~b}}\right)$ & $0.793^{* *}$ & 0.102 & 7.783 & & & & \\
\hline & Production Capability $\left(\mathrm{H}_{1 \mathrm{c}}\right)$ & -0.305 & 0.162 & -1.882 & & & & \\
\hline & International Competitive Pressure $\left(\mathrm{H}_{2}\right)$ & -0.175 & 0.071 & -2.467 & & & & \\
\hline & Research \& Development Cooperation $\left(\mathrm{H}_{3}\right)$ & $1.154^{* *}$ & 0.289 & 4.000 & & & & \\
\hline
\end{tabular}

Dependent Variable: Innovation Performance

${ }^{*} \mathrm{p}<0.05$

$\mathrm{p}<0.01$

\section{Discussions}

The analysis was conducted to shed light on the different arguments discussed in section two of this study. Three hypotheses were formulated in order to investigate the effect of some of the firms' internal capabilities such as Absorptive capacity, R\&D capability, Productive capacity; an external factor related to firms consisted of International competitive pressure, and R\&D cooperation on firms' innovation performance. While the hypotheses $1 \mathrm{~b}$ and 3 were confirmed in our findings, the hypotheses $\mathrm{H} 1 \mathrm{a}, \mathrm{H} 1 \mathrm{c}$ and $\mathrm{H} 2$ are rejected. A detailed examination and discussion of each hypothesis are provided in the following.

Although prior results $[58,21]$ demonstrated a positive impact of absorptive capacity and production capability on firms' innovation performance; our empirical findings indicate that both of them do not show any effect on firms' innovation performance in the context of Malagasy firms. The possible explanation may reside in our sample analyzed from developing countries' firms' perspective. Both factors previously mentioned constitute an important ingredient of firms' internal capabilities, and their importance has been underlined in the theory part of this paper. When assessing the level of Absorptive capacity of Malagasy firms and their production capability level, it is obviously clear that they are still falling far behind the ranks compared to those of other countries. There is a common agreement that the level of Absorptive capacity in the firm determines its internal capabilities and also its abilities to conduct external activities in order to achieve performance on innovation. Thus, one possible explanation linked to Malagasy firms' low level of absorptive capacity is attributed to their low level of knowledge resulting from the serious phenomenon of brain drain. It is important to mention that this latter is still a significant challenge for African firms [46] in their effort to improve their knowledge roots, which consequently result on the issue of non-availability of the skilled workforce. For the hypothesis 1c associated with firms' level of production capability, its low level in Malagasy firms entails into their weaknesses and their inability to undertake any innovation activities. Therefore, firms within these categories in most cases are proved to face problems to engage in any innovation activities which may result in their failure to attain performance. Besides, in the context where the aspect of the learning has focused more on application and imitation of knowledge developed elsewhere instead of the creation of knowledge [11, 59], the upgrade in firms' level of absorptive capacity and production capability occurs only when the innovation concept is well-rooted in firms' key activities. Hence, despite the fact that developing countries uphold the fertile ground for innovation [60]; there has been no significant development in firms' business environment. Only small amount of firms in Africa owns sufficient level of capability in their business operation, which consequently rate them among the low-level firms if compared to their counterparts in other countries. In our hypothesis 1, only the independent variable Research \& Development capability is supported as it shows a positive significant impact on firms' innovation performance. There is a common agreement in some authors' works $[61,62,23,28]$ indicating that $R \& D$ capability is an important tool to determine firms' performance and its success. As R\&D revealed to be a relevant element of innovation, it is through the engagement 
of firms in R\&D activities that their innovation capability may be enhanced. That is to say, the more they undertake Research and Development activities, better they are likely to achieve performance on innovation. We find the support for this finding in the work of [63] emphasizing the importance of R\&D activities for firms' innovation.

Hypothesis 2 (H2) which predicts the positive effect of international competitive pressure on firms' innovation performance is not supported in this study as its coefficient is negative $(-0.175)$. However, it revealed to have a significant $\mathrm{p}$-value $(\mathrm{p}<0.05)$. The result reveals that contrary to what was suggested in our hypothesis 2, International competitive pressure is found to affect negatively the innovation performance of firms in developing countries, like in the case of Madagascar. There exists some rationale behind this result. When analyzing the firms' level operating in developing countries, we have discovered that they are classified as a great number of micro-firms performing in informal sector with very low level of technological capability, less important number attributed to SME with minimal technological competency, then comes smaller part with technology competent firms, and few number of firms with rich Research and Development $[59,11]$. In a context where a large number of firms barely own sufficient level of capabilities in terms of innovation, a tough competition race may trump them from the market; resulting on their inabilities to undertake any innovation-related activities. Boone supported this argument by asserting that the effect of competitive pressure on faint firms (low competence firms) resulted in their exit from the market, which consequently affect negatively their innovation activities [3]. We also found Loury's statement consistent with this view [64]. The author indicated that "if greater rivalry means more firms are competing for the same prize, then a lower investment by each firm could well be outweighed by the increased number of firms". Our finding is not consistent with the prior studies [38, 37, 51].

It is also noticed from the result analysis that Research and Development Cooperation plays a significant part in firms' innovation performance as it reveals to affect it positively. The rationale behind this finding is traced back on the motivation of African firms to engage in this type of cooperation and the benefits they obtain from this cooperation. Firms in developing countries undertake R\&D Cooperation for many reasons such as to access to complementary resources from beyond their boundaries, to acquire the ability to share cost, to overcome specific obstacles to innovation, to alleviate their internal as well as external problems, to speed up their pace of innovation $[7,6$, $44,13]$. A number of scholars have considered the R\&D cooperation as beneficial to firms. For instance, Belderbos et al. reports $R \& D$ cooperation generates potential value creation for firms in their resources and cost reduction or cost saving in their innovation activities [44]. In their study of R\&D cooperation and innovation activities, Becker and Dietz also mentioned some of the benefits of $R \& D$ cooperation such as an extension of firms' technological capability and raise of the probability of innovation achievement [49].
Therefore, it may be assumed that the engagement of firms in Madagascar on R\&D Cooperation benefit them in terms of improvement in their internal as well as external capabilities which would allow them to shape their innovation performance.

In brief, this study found out that R\&D capability and R\&D Cooperation are positively associated with firms' innovation performance. In other words, they are crucial elements contributing to Malagasy firms' path to achieve innovation performance. In a context where low level of performance are attributed to the existence of some capabilities constraints (e.g. low level of internal resources) within firms or some triggers (e.g. strong competition), the awareness of the positive effect of these factors in enhancing firms' innovation performance deserves to be considered in order to further strengthen their innovation capabilities as well as their competitive advantages.

\section{Conclusion}

On the basis of a sample of 117 manufacturing firms, this study analyzes the effect of firms' internal capabilities (Absorptive capacity, Research and Development capability and Production capability) and external resource (International competitive pressure) and Research and Development Cooperation as well on their innovation performance with evidence from Madagascar. From a theoretical perspective, this paper depicts the role and importance of these previously mentioned factors complementing the limited resources on studies of firms located in developing countries, in particular, Madagascar. The empirical result of this study revealed the positive impact of Research and Development capability of firms and Research and Development Cooperation on their innovation performance, hence supporting the hypotheses $1 \mathrm{~b}$ and 3 that we put forward in our research. Contrary to what was predicted in our research and to some findings in previous studies, our results do not demonstrate any significant impact of firms' absorptive capacity and production capability level on their innovation performance probably due to the context of our study where firms still face many obstacles associated with poor business environment, low level of education, mediocre infrastructure and also low pace of innovation system $[8,59]$. The result in this study also shows that the international competitive pressure affects negatively firms' innovation performance. In the context where the subject of innovation is still very ambiguous, this study is important for managers and policy makers as it directs them on which of firms' internal resources and elements they have to focus on if part of their goals is to achieve innovation performance. The limitation of our study is related to our failure to address other sectors as part of our studied sample. Regarding the content of our study, we did not use any full mediator between our variables, which we think would have enhanced our findings. This issue is to be investigated in our future research. 


\section{Acknowledgements}

My gratitude goes first to God for all His blessings. I am also indebted to my supervisor for all her insightful discussions and critical comments in the fulfillment of the present paper. My sincere acknowledgment is attributed to my family and husband for their support.

\section{References}

[1] Lichtenthaler, U., 2009. Absorptive capacity, environmental turbulence, and the complementarity of organizational learning processes. Academy of Management Journal 52 (4), 822-846.

[2] Darai, D., Sacco, D., Schmutzler, A., 2010. Competition and innovation: an experimental investigation. Experimental Economics, 13: 439-460.

[3] Boone, J., 2000. The Effects on Investments in Product and Process Innovation. The RAND Journal of Economics, Vol. 31, 549-569.

[4] Lee. C-Y., 2009. Competition favors the prepared firm: Firms' R\&D responses to competitive market pressure. Science Direct. Research Policy 38, 861-870.

[5] Becker, W., Peters, J., 2000. Technological opportunities, absorptive capacities and innovation. Paper presented at the Eighth International Joseph A. Schumpeter Society Conference, Centre for Research in Innovation and Competition (CRIC), Manchester.

[6] Hagedoorn, J., 1993. Understanding the rationale of strategic technology partnering: Inter-organizational modes of cooperation and sectoral differences, Strategic Management Journal 14, 371-385.

[7] Miotti, L., Schwald, F., 2003. Co-operative R\&D: Why and with whom? An integrated framework of analysis. Research Policy 32, 1481-1499.

[8] Bogliacino, F., Perani G., Pianta M. \& Supino S. (2009). "Innovation in Developing Countries. The Evidence from Innovation Surveys", paper prepared for the FIRB conference Research and Entrepreneurship in the Knowledge-based Economy, Milano: Universita L. Bocconi.

[9] UNESCO SCIENCE REPORT, 2010. The current status of science around the world.

[10] Lundvall, B. A., 2007. Innovation System Research: Where it came from and where it might go. CAS Seminar, Oslo.

[11] Szogs, A., Chaminade, C., Azatyan, R., 2008. Building absorptive capacity in less developed countries: The case of Tanzania. CIRCLE. Lund University. ISSN 1654-3149.

[12] Adler, J. H., 1965. Absorptive Capacity: The Concept and Its Determinants. Brookings Institution, Washington.

[13] Cohen, W. M., Levinthal, D. A., 1990. Absorptive capacity: a new perspective on learning and innovation. Administrative Science Quarterly 35 (1), 128-152.

[14] Murovec, N., Prodan, I., 2009. Absorptive capacity, its determinants, and influence on innovation output: cross-cultural validation of the structural model. Technovation $29,859-872$.
[15] Matusik SF, Heeley M. B. (2005). Absorptive capacity in the software industry: identifying dimensions that affect knowledge and knowledge creation activities. Journal of Management 31, 549-572.

[16] Camisón C., Forés, B., (2010). Knowledge absorptive capacity: New insights for its conceptualization and measurement. Journal of Business Research 63, 707-715.

[17] Jiménez-Barrionuevon,M. M., García-Morales,V. J., MolinaL. M. (2011). Validation of an instrument to measure absorptive capacity. Technovation 31, 190-202.

[18] Wu, A., Voss H. (2015). When does absorptive capacity matter for international performance of firms? Evidence from China. International business Review 24, 344-351.

[19] Vinding, A. L., 2006. Absorptive capacity and innovative performance: a human capital approach. Economics of Innovation and New Technology 15, 507-517.

[20] Escribano, A., Fosfuri, A., Tribo', J. A., 2009. Managing external knowledge flows: the moderating role of absorptive capacity. Research Gate, Research Policy 38 (1), 96-10.

[21] Chen, Y-S., Lin M-J J., Chang C-H. (2009). The positive effects of relationship learning and absorptive capacity on innovation performance and competitive advantage in industrial markets. Industrial Marketing Management 38, 152158 .

[22] Nerkar, A., Paruchuri, S., 2005. Evolution of R\&D capabilities: The role of knowledge networks within a firm. Management Science 51, 771-785.

[23] Zhao, Z., Anand, J., Mitchell, W., 2005. A Dual Networks Perspective on Inter-Organizational Transfer of $R \& D$ Capabilities: International Joint Ventures in the Chinese Automotive. Industry Journal of Management Studies 42: 1.

[24] Paruchuri, S., Eisenman, M., 2012. Microfoundations of Firm R\&D Capabilities: A Study of Inventor Networks in a Merger. Journal of Management Studies 49: 8.

[25] Huq, M. M., 1999. Technological Capability Building in Low Income Developing Countries: Towards Understanding the Nature of the problem. Proceedings of the DSA Annual Conference, University of Bath, 11-14.

[26] Celikel, A. T., 2009. Factors Affecting Research and Development (R\&D) Collaboration of Multinational Enterprises (MNEs) and their Local Partner Firms: A Case Study of Turkish Automotive Industry. Graduate Schools of Social Sciences. Doctor of Philosophy in Contemporary Management. ISIK University.

[27] Kogut, B., Zander, U., 1992. Knowledge of the firm, combinative capabilities, and the replication of technology. Organization Science 3.

[28] Anuar, H. S., Zulhumadi, F., Udin, Z. M., 2011. Intellectual Property Rights Role in Moderating Internal and External R\&D Relationship with Operational Performance: Chemical and Metallurgical Manufacturing Firms in Malaysia. Research Gate. Innovation Vision 2020: Sustainable growth, Entrepreneurship, and Economic Development.

[29] Schumpeter, J. A. (1912/1934) English translation published in 1934. The theory of economic development. Cambridge, MA: Harvard University Press. 
[30] Helfat, C. 1997. Know-how and asset complementarity and dynamic capability accumulation: The case of R\&D. Strategic Management Journal, 18(5).

[31] Dutta, S., Narasimhan, OM., Raji, S., 2005. Conceptualizing and measuring capabilities: methodology and empirical application. Strategic Management Journal 26: 277-285.

[32] Azoulay, N., Weinstein, O., 1999. Firms' capabilities and organizational learning a critical survey of some literature. Fourth Framework Programme, European Commission.

[33] Rejal, S. H., 2004b. Assessing the Significance of Production: a firm perspective and regional implications. DRUID 2005 PhD Seminar, Aarlborg, Denmark.

[34] Fleury, A., Fleury, M. T., Borini, F. M., 2012. Is production the core competence for the internationalization of emerging country firms? INTERNATIONAL JOURNAL OF PRODUCTION ECONOMICS 140: 439-449.

[35] Crepon, B., Duguet, E., Mairesse, J., 1998. "Research, Innovation and Productivity: An Econometric Analysis at the Firm Level”. NBER Working Paper 6696.

[36] Nickel, S., 1996. Competition and Corporate Performance. Journal of Political Economy, Vol. 104, 724-746.

[37] Piga, C. A., Vivarelli, M., 2004. Internal and external R\&D: A sample Selection Approach. Oxford Bulletin of Economics and Statistics 66, 0305-9049.

[38] Vives, X., 2008. Innovation and Competitive Pressure. The Journal of Industrial Economics, Vol. 56, 419-469.

[39] Beneito, P., Coscollá-Girona, P., Rochina-Barrachina, M. E., Sanchis-Llopis, A., 2011. Competitive pressure determinants and innovation at the firm level. Journal of Industrial Economics 63.

[40] Duchek, S., 2013. Capturing Absorptive Capacity: A Critical Review and Future Prospects. Schmalenbach Business Review, Vol. 65, 312-329.

[41] Nickel, S., Nicolitsas, D., Dryden, N., 1997. What makes firms perform well? European Economic Review 41, 783-796.

[42] Veugelers, R. and B. Cassiman, 2005, R\&D Cooperation between Firms and Universities, some empirical evidence from Belgian Manufacturing. International Journal of Industrial Organisation, 23, 5-6, 355-379.

[43] Mowery, D. C., Oxley, J. E., Silverman, B. S., 1996. Strategic alliances and interfirm knowledge transfer. Strategic Management Journal 17 (Special Issue), 77-91.

[44] Belderbos, R., Carree, M., Lokshin, B., 2004. Cooperative R\&D and firm performance. Research Policy 33, 1477-1492.

[45] Aschhoff, B., Schmidt, T., 2008. Empirical Evidence on the Success of R\&D Cooperation-Happy Together? Review of Industrial Organization 33, 41-62.

[46] OECD, 2014. OECD at glance 2014, OECD INDICATORS.

[47] Veugelers, R., 1997. Internal R\&D expenditures and external technology sourcing. Research Policy 26, 303-315.
[48] Schaan, S., Anderson, F., 2001. Innovation in Canadian Manufacturing: National Estimates. Statistics Canada, Ottawa.

[49] Becker, W., Dietz, J., 2004. R\&D Cooperation and Innovation Activities of Firms-Evidence for the German Manufacturing Industry. Research Policy, Vol. 33, 209-223.

[50] Mention, A. L., 2011.Co-operation and co-opetition as open innovation practices in the service sector: Which influence on innovation novelty? Technovation 31, 44-53.

[51] Hinkkanen, J. J., Jääskeläinen, M., Väätänen, J., 2013. The role of competitive pressure in $\mathrm{R} \& \mathrm{D}$ cooperation: evidence from immature markets. International Journal of Business Innovation and research, Vol. 7.

[52] Zeng, S. X., Xie, X. M., Tam, C. M., 2010. Relationship between cooperation networks and innovation performance of SMEs. Technovation 30, 181-194.

[53] Kotabe, M., Srinivasan, S. S., Aulakh, P. S., 2002. Multinationality and firm performance. Journal of International Business Studies 33, 79-97.

[54] Zou, S., Stan, S., 1998. The determinants of export performance: a review of the empirical literature between 1987 and 1997. International Marketing Review, Vol. 15, 333356.

[55] Rasiah, R., Jaabi, S. A. K., 2014. Assessing the importance of fish exports in the economies of Uganda and the Gambia: A supply-side constraint analysis. Business Management and Economics 2, 172-185.

[56] Tang, J., 2006. Competition and innovation behaviour. Science Direct. Research Policy 35, 68-82.

[57] Nunnally, J. (1978). Psychometric Theory (2nd Ed.). New York: McGraw-Hill.

[58] Daghfous, A., 2004. Absorptive capacity and the implementation of knowledge- intensive best practices. S. A. M. Advanced Management Journal 69 (2), 21-27.

[59] Aubert, J. E., 2005. Promoting innovation in developing countries: a conceptual framework. World Bank Policy Research Working Paper 3554, April.

[60] Terrio, M. (2014). Examining Reverse Innovation and Collaboration: A Case Study in the context of Uganda. International Business Management (IDBM). Master's thesis.

[61] Prahalad, C. K., Hamel, G., 1990. The core competence of the corporation. Harvard Business Review 68, 79-91.

[62] Teece, D. J., 1981. The market for know-how and the efficient international transfer of technology. Annals of the Academy of Political and Social Science 458, 81-86.

[63] Jegede O. O., Aderemi H. O., Jesuleye O. A. and Siyanbola W.O, 2012. Status of Technological Capacity Building in the Indigenous Oilfield Servicing Firms in Nigeria vis-a-vis Innovation Capability. Greener Journal of Science Engineering and Technological Research 2, 011-016.

[64] Loury, G. C., 1979. Market Structure and Innovation. The Quarterly Journal of Economics, Vol. 93, 395-410. 